\title{
Laparoscopic paracostal herniorrhaphy in a dog: case report
}

\author{
[Herniorrafia paracostal laparoscópica em um cão: relato de caso] \\ A.B. Trindade ${ }^{1}$, P.C. Basso ${ }^{2}$, M.C. Gonçalves ${ }^{1}$, G.A. Lima ${ }^{3}$, D.G. Gerardi ${ }^{4}$, \\ C.A.C. Beck ${ }^{4}$, E.A. Contesini ${ }^{4}$, M.V. Brun ${ }^{5}$ \\ ${ }^{1}$ Aluno de pós-graduação - Universidade Federal do Rio Grande do Sul (UFRGS) - Porto Alegre, RS \\ ${ }^{2}$ Aluno de pós-graduação - Universidade Federal de Santa Maria (UFSM) - Santa Maria, RS \\ ${ }^{3}$ Aluno de graduação - Universidade Federal do Rio Grande do Sul (UFRGS) - Porto Alegre, RS \\ ${ }^{4}$ Universidade Federal do Rio Grande do Sul (UFRGS) - Porto Alegre, RS \\ ${ }^{5}$ Universidade Federal de Santa Maria (UFSM) - Santa Maria, RS
}

\begin{abstract}
Traumatic paracostal hernia is classified as an abdominal hernia that protrudes from the abdomen to a non physiologic space over the ribs. Treatment requires surgical reconstruction of the disrupted musculature in the thoracoabdominal region. Laparoscopic paracostal herniorrhaphy was performed in an eightmonth-old male Teckel, presented after a car accident injury. A three-portal laparoscopic access was used for definitive diagnosis and hernia correction. After traction of the herniated omentum, a thoracoabdominal communication caused a left side pneumothorax, which was successfully drained with a chest tube placement. The herniorrhaphy was accomplished with intracorporeal sutures by a combination of Ford interlocking and cross mattress patterns. The postoperative period was uneventful. The laparoscopic paracostal herniorrhaphy was satisfactory, allowing both diagnosis and correction of the paracostal defect, showing to be a feasible alternative to the open surgery.
\end{abstract}

Keywords: abdominal hernia; surgery; videolaparoscopy

\section{RESUMO}

A hérnia traumática paracostal é classificada como uma hérnia abdominal com abaulamento do abdômen formando um espaço não fisiológico sobre as costelas. O tratamento consiste em reconstituir cirurgicamente a musculatura rompida da região toracoabdominal. A herniorrafia paracostal laparoscópica foi realizada em um cão da raça Teckel, macho de oito meses de idade, com histórico de trauma automobilístico. Optou-se pela utilização da abordagem laparoscópica tanto para o diagnóstico definitivo quanto para a correção da mesma. Foi utilizado o acesso com três portais, permitindo a tração do omento herniado, momento este em que o animal apresentou pneumotórax devido a uma comunicação toracoabdominal esquerda. O paciente foi submetido à toracocentese e adaptação de dreno no hemitórax esquerdo. A herniorrafia foi realizada com sutura intracorpórea em padrão contínuo de colchoeiro e festonada de Ford com fio monofilamentar náilon zero. O paciente apresentou rápida recuperação pósoperatória, sem ocorrências de recidivas. Assim, a herniorrafia paracostal laparoscópica mostrou-se satisfatória, possibilitando o diagnóstico definitivo e concomitante correção do defeito abdominal e diafragmático, podendo ser indicada como uma alternativa à cirurgia convencional.

Palavras-chave: hérnia abdominal, cirurgia, videolaparoscopia

\section{INTRODUCTION}

Traumatic hernias in the abdominal wall are characterized by muscular disruption caused by a direct trauma without skin penetration or evidence of preexisting hernias at the wounded site (Damschen et al., 1994; Moreno-Egea et al., 2007). Due to the absence of a hernial sac, they are classified as false hernias (Smeak, 2007).

Recebido em 25 de junho de 2012

Aceito em 17 de julho de 2013

E-mail: anelisebt@yahoo.com.br 
These abdominal hernias can still be defined, depending on their location, as ventral, prepubic, subcostal, hypochondral, paracostal, or lateral hernias (Soldá, 2002).

The injuries at the thoracoabdominal region, such as paracostal hernias, often cause diaphragmatic damage as well. However, it is not uncommon to have such lesions being misdiagnosed or not promptly identified due to unspecific signs and inconclusive radiographic images. Small lesions can even remain undiagnosed for months or years after the initial trauma and may only be suspected when the patient starts showing significant dyspnea or signs of intrathoracic strangulation of abdominal organs (Lenot et al., 1990). Indeed, diagnosis often occurs as a transoperative finding, when surgical interventions are indicated for investigation or treatment of associated abdominal viscera damages or peritoneal irritation (Soldá, 2002).

To repair a traumatic hernia, surgical reconstruction of the ruptured musculature is entailed (Moreno-Egea et al., 2007, Smeak, 2007). Either conventional open procedure or laparoscopic approach can be performed for operative access (Moreno-Egea et al., 2007). It is known that laparoscopic surgery, compared to conventional operation, reduces surgical wounds, diminishes postoperative pain and discomfort, reduces hospitalization time, and, consequently, lowers hospitalization costs (Remedius and Fergusson, 1996; Trindade et al., 2010).

The reconstruction of the abdominal and thoracic wall by minimally invasive surgery is still recent, having been described for the first time by Ger, in 1982. However, it achieved notoriety only after 1990, when it started to improve both technologically and surgically (Lau et al., 1997). Today, with a substantial worldwide human casuistic and some cases reported in veterinary medicine, the videolaparoscopy is being appreciated for treatment of hernias, as, in addition to the aforementioned advantages, the magnification of images turns out to be a detailed diagnostic resource and provides the surgeon with a better sight (Brun et al., 2004; Brun et al., 2006).
This report describes the diagnosis and treatment of a paracostal hernia through minimally invasive surgery in veterinary medicine.

\section{CASE REPORT}

An eight-month-old male Teckel, weighing $8 \mathrm{~kg}$, was attended at the Veterinary Hospital of Passo Fundo University (UPF, Brazil) five days after colliding with a car, showing swelling in the abdominal wall and local pain.

At clinical examination, assessment of mucosal color, capillary refill time, body temperature, and cardiopulmonary auscultation showed no abnormal findings. A slight dyspnea with a bulging in the left thoracoabdominal region was observed during general clinical inspection. Although at palpation of the meso and hypogastric abdominal regions, no alterations or pain were observed, in the left epigastric region, near the bulging, local soreness was detected. In addition to edema and muscular contusion, a fracture in the thirteenth left rib was suspected along with a diaphragmatic or paracostal hernia.

Abdominal and thoracic radiographs revealed integrity of the ribs and diaphragmatic line, suggesting absence of either diaphragmatic hernia or rib fracture. Abdominal ultrasound revealed normal anatomical position of viscera and a fat-like content in the swollen region at the left thoracoabdominal wall. Results of complete blood count and biochemical profile were within the normal limits for the specie.

Since the possibility of traumatic left paracostal hernia was still considered, after hospitalization for stabilizing the animal's general condition, videolaparoscopy was performed for definite diagnosis and possible surgical treatment.

Association of acepromazine $0.05 \mathrm{mg} \cdot \mathrm{kg}^{-1}$, IM (Bayer S.A, Brazil) and morphine sulphate $0.3 \mathrm{mg} . \mathrm{kg}^{-1}$, IM (Cristália Produtos Químicos Farmacêuticos Ltda, Brazil) was administered as pre-anesthetic medication. General anesthesia was achieved by induction with midazolam $0.3 \mathrm{mg} \cdot \mathrm{kg}^{-1}$, IV (União Química, Brazil) and ketamine chloridrate $5.0 \mathrm{mg} \cdot \mathrm{kg}^{-1}$, IV (União Química, Brazil), followed by maintenance with isoflurane vaporized in $100 \% \mathrm{O}_{2}$ in a semi-open circuit. Epidural block was done with lidocaine 2.0mg. $\mathrm{kg}^{-1}$ (Astrazeneca do Brasil Ltda, Brazil) 
and morphine $0.1 \mathrm{mg} \cdot \mathrm{kg}^{-1}$. Ampicillin sodium $22 \mathrm{mg} . \mathrm{kg}^{-1}$, IV (Eurofarma Laboratórios Ltda, Brazil) was used for antibiotic prophylaxis.

With the animal in right lateral recumbency, three trocars (Edlo S/A®, Brazil), two of 10-mm and one of 5-mm of diameter, were introduced in the left abdominal wall, immediately caudal to the swollen region, in a triangular arrangement under visualization with a $10 \mathrm{~mm}$ rigid endoscope (Karl Storz Endoskope, Germany). The abdominal cavity was inflated $(12 \mathrm{mmHg})$ with $\mathrm{CO}_{2}$ (Astus Medical®, Brazil).

At inspection of the whole abdominal cavity, the left paracostal defect was identified, the omentum being the only herniated content (Figure 1).

During the repositioning of the omentum and beginning of the herniorrhaphy, the animal presented intense dyspnea, mucosal cyanosis, and pneumothorax. At this point, the procedure was interrupted and the abdominal cavity insufflation was discontinued for about 30 minutes. A chest tube was placed in the left hemithorax and drainage was carried out until patient respiration was stabilized. It was not possible to visualize a diaphragmatic lesion that could explain the air going into the chest. More likely, it could have been due to a possible paracostal communication of the hernia with the thorax.

The omentum was carefully pulled out with Babcock forceps (Edlo S/A®) through the diaphragmatic defect back to the abdomen. The apposition of the defect edges was first started with Ford interlocking pattern and then concluded with cross mattress sutures, using a combination of 0 nylon, 0 polyglycolic acid and 0 polypropylene suture materials (Figure 2 ).

After inspection and deflation of the abdominal cavity, the skin portal incisions were closed with 2-0 polyglycolic acid sutures in simple interrupted pattern. In the postoperative period, $0.9 \% \mathrm{NaCl}$ was used for daily cleaning of the surgical wounds. Morphine sulphate $0.3 \mathrm{mgkg}^{-1}$, four times daily, for two days, ketoprofen $1.2 \mathrm{mgkg}^{-1}$, once a daily, for three days (Eurofarma Laboratórios Ltda, Brazil) and cephalotin $20 \mathrm{mgkg}^{-1}$, three times daily, for two days (Eurofarma Laboratórios Ltda, Brazil), were also prescribed postoperatively. All the drugs were administered subcutaneously during hospitalization.

During the postoperative hospitalization time, the animal was active and showed no signs of pain. Thoracic drainage was only performed when the animal presented dyspnea, and the drain was removed 48 hours after the surgical procedure.

The animal was discharged with antibiotic prescription of oral cephalexin (Eurofarma Laboratórios Ltda, Brazil), $20 \mathrm{mg} \cdot \mathrm{kg}^{-1}$, twice daily, for five more days. Eight days after the surgical procedure, the dog returned for skin suture removal, showing good surgical wound healing and no signs of hernia recurrence or local alterations (Figure 3).

\section{RESULTS AND DISCUSSION}

The dog presented with alterations in the abdominal wall due to a car accident trauma. It is known from the literature that (Smeak, 2007), car accidents or contusions are the main cause for thoracoabdominal trauma that leads to rupture of these cavities' walls. The inguinal, prepubic, and the paracostal areas present the largest incidence of abdominal hernias. Among the thoracic lesions, the diaphragm is the most affected, young male dogs being the most representative population (Moreno-Egea et al., 2007; Smeak, 2007; Unlu et al., 2007).

During the clinical examination of the animal, an irreducible saliency under the skin in the left paracostal region, along with an abdominal contour asymmetry was noticed. Such alteration could be suggestive of paracostal hernia, since the region next to the costal arch is a delicate zone of the abdominal wall. However, the clinical suspicion was not confirmed by the routine imaging. The verification of irreducible or ill-defined traumatic abdominal hernias can be challenging due to some lack of specificity or sensitivity of its clinical, ultrasonographic and radiographic features (Moreno-Egea et al., 2007; Smeak 2007). Nonetheless, in these cases, laparoscopy can be used as a diagnostic resource, since it provides the surgeon with a detailed field through image magnification, allowing the localization and, eventually, the correction of defects of the musculature. Likewise, laparoscopy has been chosen to conduct a variety 
of abdominal explorations with a wide range of indications, enabling evaluation of adjacent structures for diagnostic purposes and therapy (Lau et al., 1997). The preoperative exams performed in the patient allowed evaluation of the animal's general condition and hemodynamic stability, providing sufficient criteria for proper indication of laparoscopy.

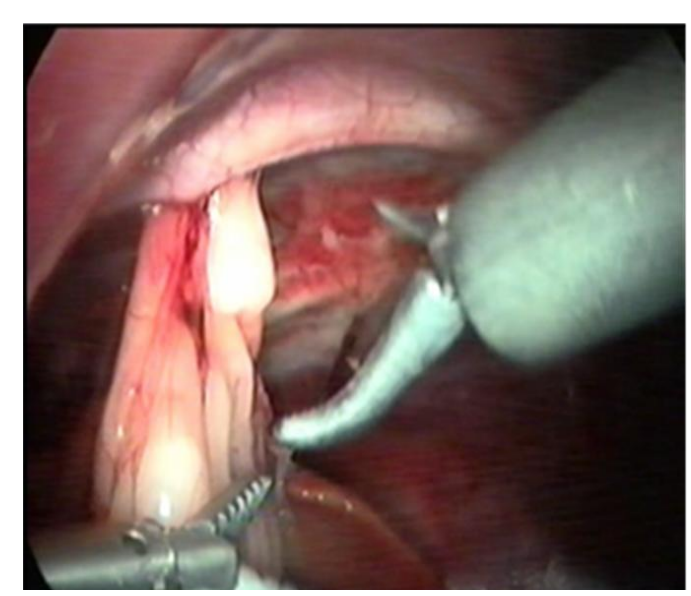

Figure 1. Left paracostal hernia in an eightmonth-old dog. Videolaparoscopic image shows the lesion on the left abdominal wall during the identification of the omentum as the herniated content.

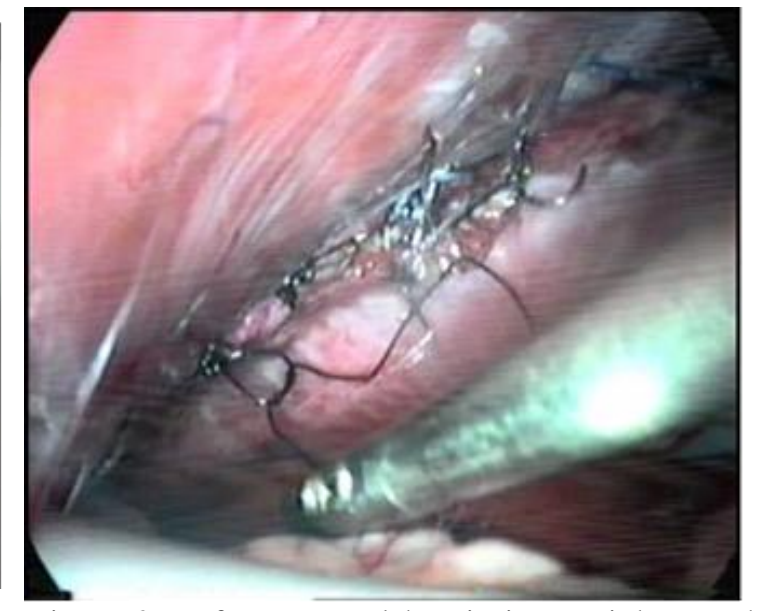

Figure 2. Left Paracostal hernia in an eight-monthold dog. Videolaparoscopic image shows intracorporeal suturing of the thoracoabdominal defect.

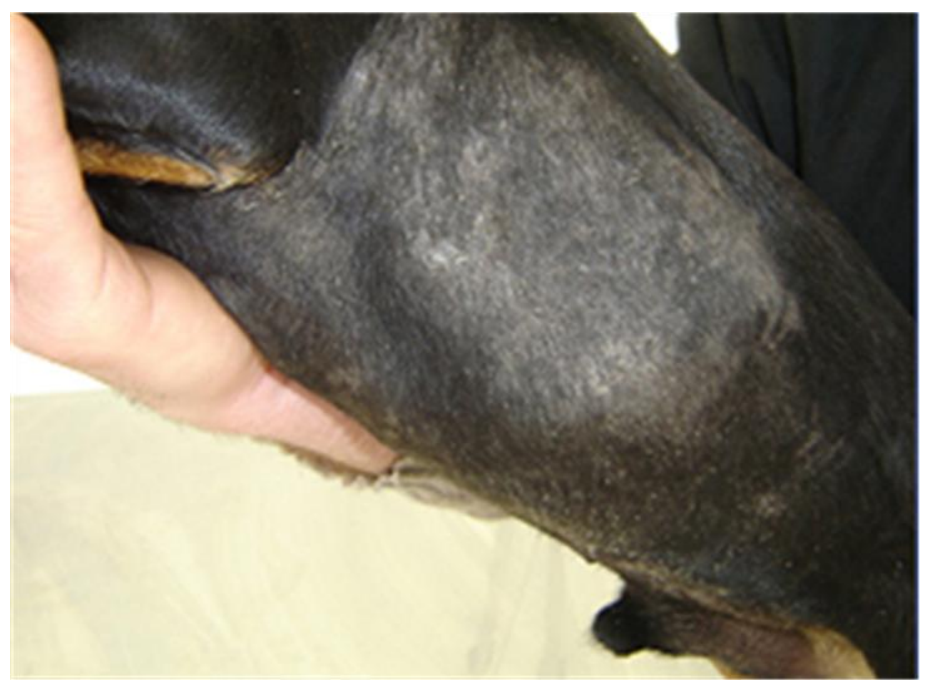

Figure 3. Eight-month-old dog, submitted to videoloparoscopy for treatment of a left paracostal hernia. Eight days after surgical procedure, small scars can be seen in the left abdominal wall where the trocars were inserted (arrows).

Given that the alterations present in the hernias are anatomical, the treatment is only accomplished by surgical reconstruction of the disrupted musculature (Smeak, 2007). The most common surgical approach for traumatic abdominal herniorrhaphy is middle line laparotomy or laparoscopy (Brun et al.,
2006). In this case, laparoscopy allowed extensive observation of the abdomen and diaphragm, identification of the omentum as the only hernia content, and traction of this tissue. Unlu et al. (2007), in a work conducted with human patients, found the omentum to be the 
main structure protruding into intercostal hernias, followed by the colon and small intestine.

The laparoscopic procedure for the herniorrhaphy lasted 182 minutes. Such surgical time can be considered long if compared to those obtained by Brun et al. (2006) in laparoscopic abdominal and inguinal hernia repair. The longer time, in this case, can be partially explained by the interruption of the surgical procedure for thoracic drainage after the unpredictable pneumothorax.

The failure to detect either a small diaphragmatic or parietal pleura lesion before herniorrhaphy could have been due to a negative pressure gradient between the thoracic and abdominal cavities that establishes, at first, a suction of the abdominal viscera into the thorax, blocked the lesion opening. Probably, the traction of the omentum back to the abdomen, during the surgical procedure, allowed the communication between the cavities to form a pneumothorax, as the $\mathrm{CO}_{2}$ escaped to the chest. Although, laceration at the diaphragm was not identified during surgery, it is possible that an existing injured margin would have been incorporated to the suture of the adjacent thoracoabdominal wall muscles during herniorrhaphy. If the communication between cavities was due to a defect at the parietal pleura and intercostal muscles, the closure of the thoracoabdominal defect was sufficient to prevent the air from going back to the thoracic cavity. Despite the inconvenience of the patient's breathing instability promoted by the pneumothorax, it allowed the diagnosis of a thoracoabdominal communication, since it could have been easily missed by the surgeons and lead to a postoperative complication if not solved during surgery. Pneumothorax is not frequently observed, during surgery, in human patients with diaphragmatic lesions even after removal of the viscera back to the abdomen, possibly due to the positive pressure produced by the mechanical ventilation (Soldá, 2002). In the present case, the patient was kept under assisted-ventilation. Thus, the entrance of $\mathrm{CO}_{2}$ into the thorax with the releasing of the omentum was detected by the respiration distress and abnormal diaphragm movement. At that moment, the procedure was interrupted and insufflation stopped for some minutes to reduce intra-abdominal pressure and allow drainage of the thorax for stabilization of the patient. A thoracic drain was placed only in the left side, since dogs can have mediastinal pleura splitting the pleural cavity in two hemithoraxes (Unlu et al., 2007) and the lesion was limited to the left one.

Although some authors suggest the use of synthetic mesh for hernia closing, this material was not necessary because the intracorporeal sutures were sufficient for good margin apposition (Moreno-Egea et al., 2007).

We conclude that the laparoscopic herniorrhaphy showed to be satisfactory since it allowed visualization of the abdominal structures without unnecessary thoracic and abdominal cavities exposure and lead to definitive diagnosis and proper treatment. It can be considered, depending on the patient's clinical condition, as an alternative to the conventional open technique for management of paracostal hernias in dogs.

\section{REFERENCES}

BRUN, M.V; BECK, C.A.C.; BARCELLOS, H.H.A. Tratamento de hérnia inguinal indireta em dois cães por cirurgia laparoscópica. Bras. J. Vet. Res. Anim. Sci., v.41, p.106-107, 2004.

BRUN, M.V.; TRINDADE, A.B.; PÖHL, VH. et al. Laparoscopic hernia repair in dogs. Arq. Bras. Med. Vet. Zootec., v.58, p.1-145, 2006.

DAMSCHEN, D.D.; LANDERCASPER, J.; COGBILL, T.H. et al. Acute traumatic abdominal hernia: case reports. J. Trauma., v.36, p.73-276, 1994.

GER, R. The management of certain abdominal herniae by intra-abdominal closure of the neck of the sac. Preliminary communication. Ann. R. Coll. Surg. Engl., v.64, p.342-344, 1982.

LENOT, B.; BELLENOT, F.; REGNARD, J.F. et al. Les ruptures du diaphragme de revelation tardive. Ann. Chir: Chir thorac cardiovasc., v.44, p.157-160, 1990.

MORENO-EGEA, A.; GIRELA, E.; PARLORIO, E.; AGUAYO-ALBASINI, J.L. Controvérsias en el manejo actual de lãs hérnias traumáticas de pared abdominal. Cir.Esp., v.82, p.260-267, 2007.

SMEAK, D.D. Abdominal hérnias. In: Slatter D. (Ed). Manual de cirurgia de pequenos animais. W.B. Saunders: Philadelphia, 2007. p.449-470. 
SOLDÁ, S.C. Laparoscopy in abdominal trauma. Rev Col Bras Cir., v.29, p.49-53, 2002.

TRINDADE, A.B.; BRUN, M.V.; BASSO, P.C. et al. Ovário-histerectomia videoassistida em uma cadela com hematometra- Relato de caso. Cienc. Anim. Bras., v.11, p.226-233, 2010.

REMEDIUS, A.M.; FERGUSSON, J. Minimally invasive surgery: laparoscopy and thoracoscopy in small animal. Comp. Cont. Educ. Pract. Vet., v.18, p.1191-1199, 1996.
LAU, W.Y.; LEOW, C.K.; LI, A.K.C. History of endoscopic and laparoscopic surgery. World J. Surg., v.21, p.444-453, 1997.

UNLU, E.; TEMIZOZ, O.; CAGLI, B. Acquired spontaneous intercostal abdominal hérnia: Case report and comprehensive review of the world literature. Australas Radiol., v.51, p.163-167, 2007. 